\title{
Synthesis and Characterization of Controlled-Release Urea Fertilizer from Superabsorbent Hydrogels
}

\author{
Salih Muharam ${ }^{1, *}$, Afria Fitri ${ }^{1}$, Lela Mukmilah Yuningsih ${ }^{1}$, \\ Yulia Mariana Tessa Ayudia Putri ${ }^{2}$, and Isnaini Rahmawati ${ }^{2}$ \\ ${ }^{1}$ Department of Chemistry, Faculty of Science and Technology, Muhammadiyah University of Sukabumi, \\ Jl. R. Syamsudin S.H. No. 50, Cikole, Sukabumi 43113, West Java, Indonesia \\ ${ }^{2}$ Department of Chemistry, Faculty of Mathematics and Natural Sciences, Universitas Indonesia, \\ Pondok Cina, Depok 16424, West Java, Indonesia
}

\section{*Corresponding author: \\ email:salih.ummi@gmail.com}

Received: March 18, 2019

Accepted: October 1, 2019

DOI: $10.22146 / \mathrm{ijc} .44230$

\begin{abstract}
It is very important to develop controlled-release fertilizers to ensure efficiency and environmental protection. This study aims to make a superabsorbent hydrogel-based controlled-release urea fertilizer. Superabsorbent hydrogels were prepared from the cellulose of corn cobs cross-linking with epichlorohydrin, and then an amount of urea as a fertilizer was stored inside the hydrogels (GEL-A). The GEL-A functionalization with carboxy-methyl was also carried out in this study to improve the hydrophilicity of hydrogels (GEL-B). GEL-A and GEL-B were immersed in water at a certain $p H$ and temperature range and the urea concentration released from the hydrogels was monitored by a spectrophotometer. The results showed that the urea released by GEL-A and GEL-B was not much different. Respectively, the urea efficiency of GEL-A and GEL-B was around $5.29 \%$ and $5.56 \%$ for $180 \mathrm{~min}$. The urea released from both hydrogels was not significantly affected by changes in the temperature of the solution. Urea release was influenced by $p H$, and the rate of urea release of GEL-B was faster than GEL-A, so $\mathrm{pH}$ control was needed in the application of this slow-release fertilizer.
\end{abstract}

Keywords: fertilizer; cellulose; superabsorbent hydrogel; slow-release fertilizer

\section{- INTRODUCTION}

Continuous use of fertilizers in agriculture, especially nitrogen fertilizers can cause environmental problems [1]. Urea is the most widely used fertilizer because it has high nitrogen content (46\%). On the other hand, the efficiency of urea uptake by plants generally ranges under $50 \%$ due to surface runoff, washing, and evaporation, causing urea to be accumulated in the water and cause very serious environmental problems [2] when converted into a toxic compound of nitrite.

Agricultural technology has developed many fertilizers that can be released slowly or controlled in the soil [3-4]. The performance of such fertilizers provides a large amount of fertilizer, but protect it from rapid release due to evaporation and infiltration. The fertilizer release mechanism is the transfer of nutrients from the fertilizer- polymer interface to the polymer-soil interface [5] in the form of an adsorption-desorption process. The adsorption-desorption process is an equilibrium reaction, so it is influenced by changes in $\mathrm{pH}$ and temperature and also by the characteristics of the coating material, the type of fertilizer release material, and agronomic conditions.

The controlled release of fertilizers is carried out by materials such as hydrogels, polyolefins or resins and other polymer layers [1]. The formation of hydrogels with a cross-linking process will produce 3D macromolecules that have low solubility in water but absorb large amounts of water [6]. Hydrogels are generally obtained from natural sources (natural hydrogels) or are synthesized through chemical reactions. Naturally-sourced hydrogels are often called biopolymer-based hydrogels, which have some 
advantageous attributes, unlike synthetic hydrogels, in terms of biocompatibility, biodegradability, non-toxicity, and bio-mimic traits. The appealing functions of cellulose-based hydrogels have inspired researchers throughout the globe to develop new materials for myriad applications in various fields, such as biomedical engineering (tissue engineering, wound dressing, drug delivery system), development of smart materials (sensors, actuators), advancement in healthcare and hygienic products (diapers, napkins) along with improvement in agriculture (pesticide carriers, water reservoir, water retention) [7].

Natural polymers have biocompatibility and lower toxic effects compared to the synthetic ones [8]. In this study, cellulose-based superabsorbent hydrogels was prepared using the epichlorohydrin crosslinking method to form a hollow or porous cellulose structure as a storage medium for fertilizers and release medium for the controlled release of urea.

\section{- EXPERIMENTAL SECTION}

\section{Materials}

The materials used were corn cobs as a source of cellulose, epichlorohydrin, ethanol, $\mathrm{CaCO}_{3}, \mathrm{HNO}_{3}$, $\mathrm{NaNO}_{2}, \mathrm{Na}_{2} \mathrm{SO}_{3}, \mathrm{NaOCl}, \mathrm{NaOH}, \mathrm{CO}\left(\mathrm{NH}_{2}\right)_{2}$, chloroacetic acid, 2-propanol, buffer solutions, $\mathrm{ZnSO}_{4}$ and Nessler's reagent.

\section{Instrumentation}

The instruments used were SEM JEOL JED-2300, Bruker FTIR Spectrometer, and HACH DR-2000 Spectrophotometer.

\section{Procedure}

\section{Isolation of a-cellulose}

In $75 \mathrm{~g}$ of corn cobs, $3.5 \% \mathrm{HNO}_{3}(\mathrm{v} / \mathrm{v})$ and $10 \mathrm{mg}$ $\mathrm{NaNO}_{2}$ were mixed, and then the mixture was heated at $90^{\circ} \mathrm{C}$ for $2 \mathrm{~h}$ and the residue was refluxed with a mixture of $2 \% \mathrm{NaOH}(\mathrm{w} / \mathrm{v})$ and $2 \% \mathrm{Na}_{2} \mathrm{SO}_{3}(\mathrm{w} / \mathrm{v})$ at $50{ }^{\circ} \mathrm{C}$ for $1 \mathrm{~h}$. Next, it was purified with $1.75 \% \mathrm{NaOCl}(\mathrm{v} / \mathrm{v})$ at $100{ }^{\circ} \mathrm{C}$ for $1 \mathrm{~h}$ and was then hydrolyzed with $17.5 \% \mathrm{NaOH}(\mathrm{w} / \mathrm{v})$ at $80^{\circ} \mathrm{C}$ for $30 \mathrm{~min}$. In the final stage, the residue was washed with distilled water and dried in an oven at $60{ }^{\circ} \mathrm{C}$ [9-10]. The produced dry powder was characterized using FTIR.

\section{Synthesis of superabsorbent hydrogels}

Preparation of GEL-A. In $3 \mathrm{~g}$ of cellulose, $98 \mathrm{~g}$ of a mixture of $6 \% \mathrm{NaOH}(\mathrm{w} / \mathrm{w}), 4 \%$ urea (w/w), $90 \%$ water $(\mathrm{w} / \mathrm{w})$ and $\mathrm{CaCO}_{3}$ were added, and then the mixture was stirred for $5 \mathrm{~min}$ and cooled for $24 \mathrm{~h}$ in the refrigerator to form a transparent cellulose gel. Epichlorohydrin $10 \%(\mathrm{v} / \mathrm{v})$ was added to the mixture and stirred at $30{ }^{\circ} \mathrm{C}$ for $2 \mathrm{~h}$ and filtered to separate the gel. The gel was then washed with distilled water and dried at $40^{\circ} \mathrm{C}$ to produce GEL-A [8]. GEL-A was characterized by FTIR.

Preparation of GEL-B. A certain amount of GEL-A was functionalized by adding $6.75 \mathrm{~g} \mathrm{NaOH}, 40 \mathrm{~mL}$ of 2-propanol, and $10 \mathrm{~mL}$ of distilled water, and then the mixture was added by $7.5 \mathrm{~g}$ of chloroacetic acid in $10 \mathrm{~mL}$ of 2-propanol. The mixture was stirred for $4 \mathrm{~h}$, filtered and washed with ethanol and dried at $40{ }^{\circ} \mathrm{C}$ for $3-12 \mathrm{~h}$ [11] to form GEL-B. Furthermore, it was characterized by FTIR.

Swelling capacity measurement. The swelling capacity of GEL-A and GEL-B in the water was measured by soaking both gels in nylon containers filled with water for $24 \mathrm{~h}$ at room temperature. The swelling ratio was calculated using this equation [12]:

$\%$ Swelling $=\frac{M_{S}-M_{o}-M_{n}}{M_{o}} \times 100$

where $\mathrm{M}_{\mathrm{s}}$ : swollen hydrogel weight, $\mathrm{M}_{1}$ : dried cellulose hydrogel and $\mathrm{M}_{\mathrm{o}}$ : wet nylon bag weight.

Measurement of absorbed urea concentration. GEL-A and GEL-B were individually soaked in 100 ppm of urea solution for $24 \mathrm{~h}$ at room temperature and were then filtered, and the urea residue in the filtrate was measured by a spectrophotometer [13]. The amount of urea concentration absorbed into the gels is the deviation of the urea concentration in the solution from the urea concentration in the filtrate. Furthermore, the gels that had been soaked were characterized by SEM and FTIR [12].

Measurement of urea released from GEL-A and GEL-B. GEL-A and GEL-B were individually soaked in $250 \mathrm{~mL}$ of water for 15-180 min while being stirred constantly at room temperature. The urea which was released every 15 min was monitored by measuring the urea concentration in the solution with a 
spectrophotometer [13]. In addition, the urea released from GEL-A and GEL-B was analyzed in media with $\mathrm{pH}$ 5-9 and temperatures $18-46{ }^{\circ} \mathrm{C}$. The urea concentration in the solution was measured by the same technique.

\section{- RESULTS AND DISCUSSION}

\section{Isolation of $\alpha$-Cellulose}

Delignification process was carried out by a multistage pulping method using a mixture of $3.5 \% \mathrm{HNO}_{3}$ and $\mathrm{NaNO}_{2}$. This process converts lignin to nitro lignin while eliminating hemicellulose [14]. The surface of the fibers at this stage appeared to be rougher, showing the removal of some outer non-cellulose layers such as hemicellulose, lignin, pectin and minerals [15]. Reheating was carried out in the second stage with a mixture of $2 \%$ $\mathrm{NaOH}$ and $2 \% \mathrm{Na}_{2} \mathrm{SO}_{3}$ to complete lignin release. The next stage was the bleaching process by adding $1.75 \%$ $\mathrm{NaOCl}$, accompanied by heating to form holocellulose [14]. Next, the hydrolysis process using $17.5 \% \mathrm{NaOH}$ was conducted to produce pure $\alpha$-cellulose [16].

\section{Synthesis and Characterization of Superabsorbent Hydrogels}

Hydrogels were prepared from cellulose in an aqueous solution of $\mathrm{NaOH} /$ urea with the addition of $\mathrm{CaCO}_{3}$ as a pore forming material. Kabiri and ZohuriaanMehr [17] reported that the swelling ratio of superabsorbent hydrogels can be enhanced through porosity formed in the hydrogel structure. The physical gelation process was carried out through cooling for $24 \mathrm{~h}$ and the results showed that cellulose was well dispersed in the solution. Cellulose molecules in the aqueous solution below $0{ }^{\circ} \mathrm{C}$ have strong intermolecular interactions and relatively more rigid chains, while those above $0{ }^{\circ} \mathrm{C}$ are converted to semi flexible chain conformation. Intermolecular interactions of cellulose are much stronger than between cellulose hydrates, $\mathrm{NaOH}$ hydrates, urea hydrates, and water molecules below $0{ }^{\circ} \mathrm{C}$. Therefore, cellulose can be dissolved in $\mathrm{NaOH} / \mathrm{urea}$ that is cooled to $-10{ }^{\circ} \mathrm{C}$, and the cellulose solution formed cannot remain in its liquid state below $0{ }^{\circ} \mathrm{C}$ for a certain time, indicating an irreversible sol-gel transition [18].

The cross-linking reaction of cellulose increases the specific degree of swelling and stable structure [19]. Epichlorohydrin (ECH) is a cross-linking agent whose reaction is catalyzed by bases $(\mathrm{NaOH}, \mathrm{LiOH}$, etc.) and is widely used for polysaccharide chains. The cross-linking process is controlled by the synergy between the chemical and physical cross-linking processes, namely the etherification reaction between the hydroxyl group of ECH and the cellulose chain (Fig. 1), as well as the cellulose chain winding through the reconstruction of hydrogen bonds in various alkaline media $(\mathrm{NaOH}$, $\mathrm{NaOH} /$ urea, $\mathrm{NaOH} /$ thiourea, or $\mathrm{LiOH} /$ urea) [20].

Cellulose-ECH hydrogels are functionalized under alkaline conditions because the etherification reaction can be accelerated by the alkali/protonation process [11]. The hydroxyl group $(-\mathrm{OH})$ of the cellulose molecules is activated and converted to a more reactive alkoxide $\left(\mathrm{Cell}-\mathrm{O}^{-}\right)$form as shown in Fig. 2 [21]. Etherification takes place in the second stage. The role of the solvent in this reaction is to provide accessibility of the etherification reagent to the reaction center of the cellulose chain [22].

The swelling ratio has a linear correlation to the absorption capacity, where a high swelling ratio indicates

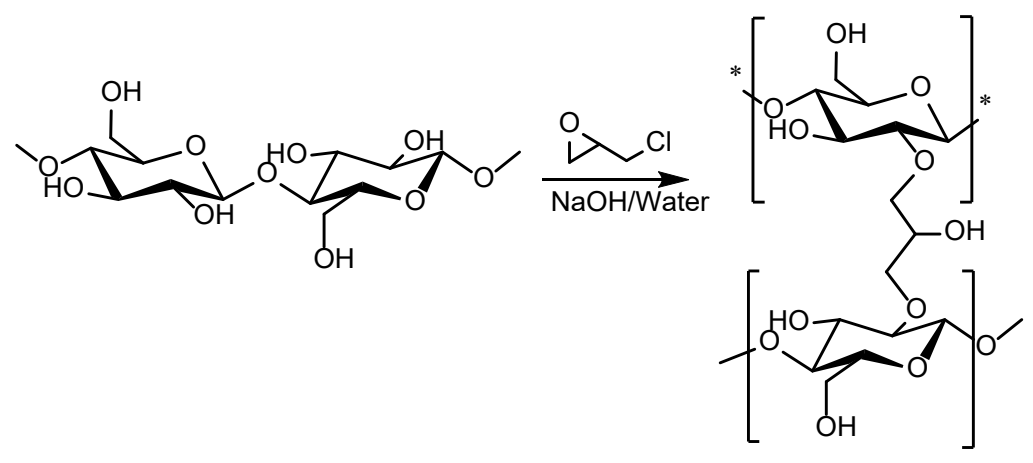

Fig 1. Mechanism of cellulose cross-linking with ECH [19] 

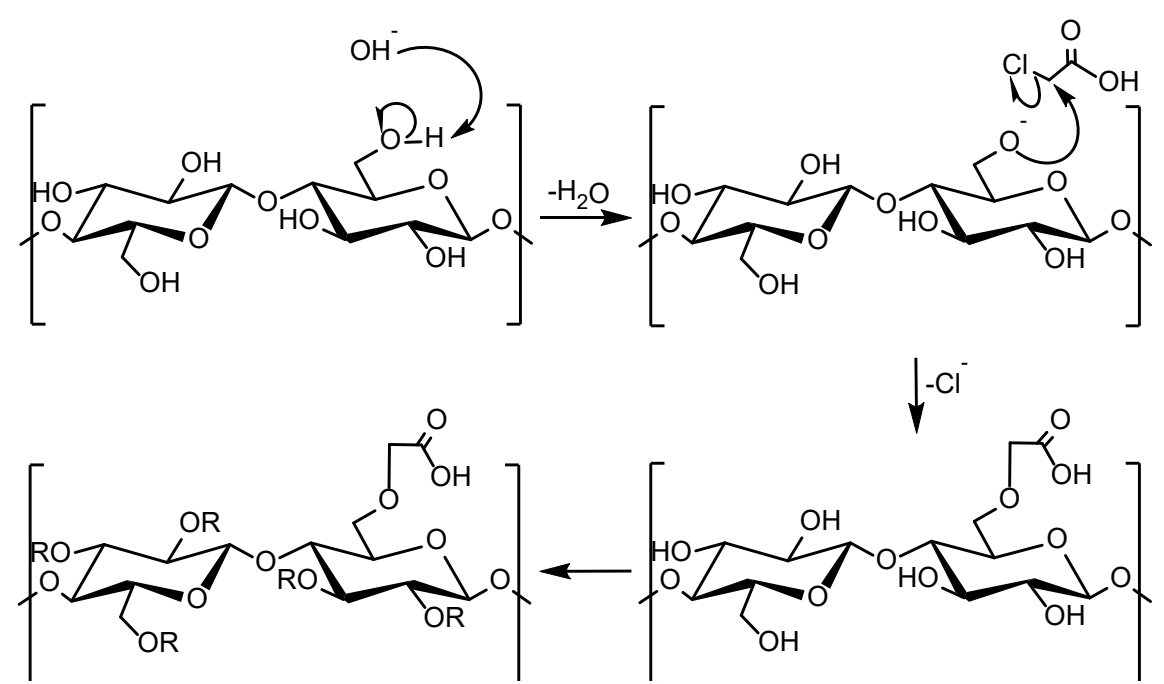

Fig 2. The mechanism for carboxymethylation of cellulose [23]

a high absorption capacity [12]. Table 1 shows the comparison of the swelling ratio of the hydrogels measured for $24 \mathrm{~h}$. The swelling ratio of GEL-B was greater than that of GEL-A, due to the addition of the carboxymethyl group. The acidic characteristic of carboxymethyl causes hydrogels to be more polar, easily resonated and become more stable, resulting in greater water binding ability [11]. The swelling ratio of the hydrogels is affected by the degree of cross-linking, but it can also be affected by elasticity interaction, polymer-solvent interaction, electrostatic repulsion and osmotic pressure [12]. GEL-B after swelling appeared to be more transparent (Fig. 3(d)), showing greater water absorption, and this is the same as what was stated by Chang et al. [8], the increased space in a hydrogel material is caused by a highly hydrophilic carbonyl group that can absorb many water molecules. When applied to agricultural land, a higher water retention capability can reduce the evaporation rate of water and consequently reduce the loss of fertilizer migrating to the soil surface [24]. It should be noted that on the ground, each hydrogel particle is surrounded by soil particles under the limiting pressure from the soil. Thus, the swelling rate of hydrogels would decrease in the soil [25].

The addition of fertilizer into hydrogel material was carried out by immersing GEL-A and GEL-B into the urea solution. Based on Table 2, greater urea absorption was achieved by GEL-B. In the urea solution, there is a group that has more hydrophilic sites such as $-\mathrm{NH}_{2}{ }^{+}$and $\mathrm{C}=\mathrm{O}$ and will interact with $-\mathrm{COOH}$ group of hydrogels easily [26].

Table 1. Swelling ratio comparison of GEL-A and GEL-B

\begin{tabular}{ccccc}
\hline Sample Code & Ms $(\mathrm{g})$ & Mo $(\mathrm{g})$ & Mn $(\mathrm{g})$ & \% Swelling \\
\hline GEL-A & 2.4553 & 0.5005 & 0.9804 & 194.68 \\
GEL B & 5.4058 & 0.5017 & 0.9642 & 785.30 \\
\hline
\end{tabular}
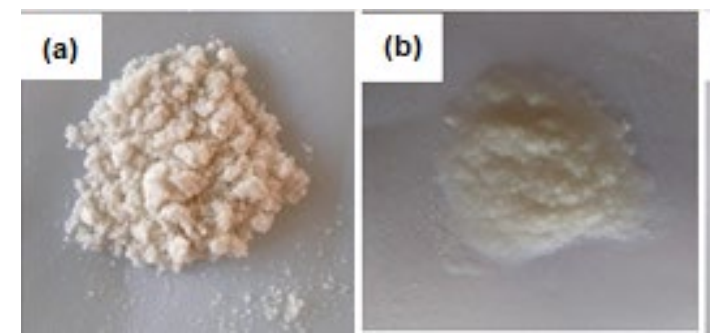

(c)

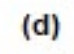

Fig 3. Hydrogels; (a) dried GEL-A, (b) swollen GEL-A, (c) dried GEL-B, (d) swollen GEL-B 
Table 2. Urea absorption comparison of GEL-A and GEL-B

\begin{tabular}{ccc}
\hline Sample Code & $\begin{array}{c}\text { Total Urea Concentration } \\
(\mathrm{ppm})\end{array}$ & $\begin{array}{c}\text { Absorbed Urea Concentration } \\
(\mathrm{ppm})\end{array}$ \\
\hline GEL-A & 100 & 97.75 \\
GEL-B & 100 & 98.33 \\
\hline
\end{tabular}
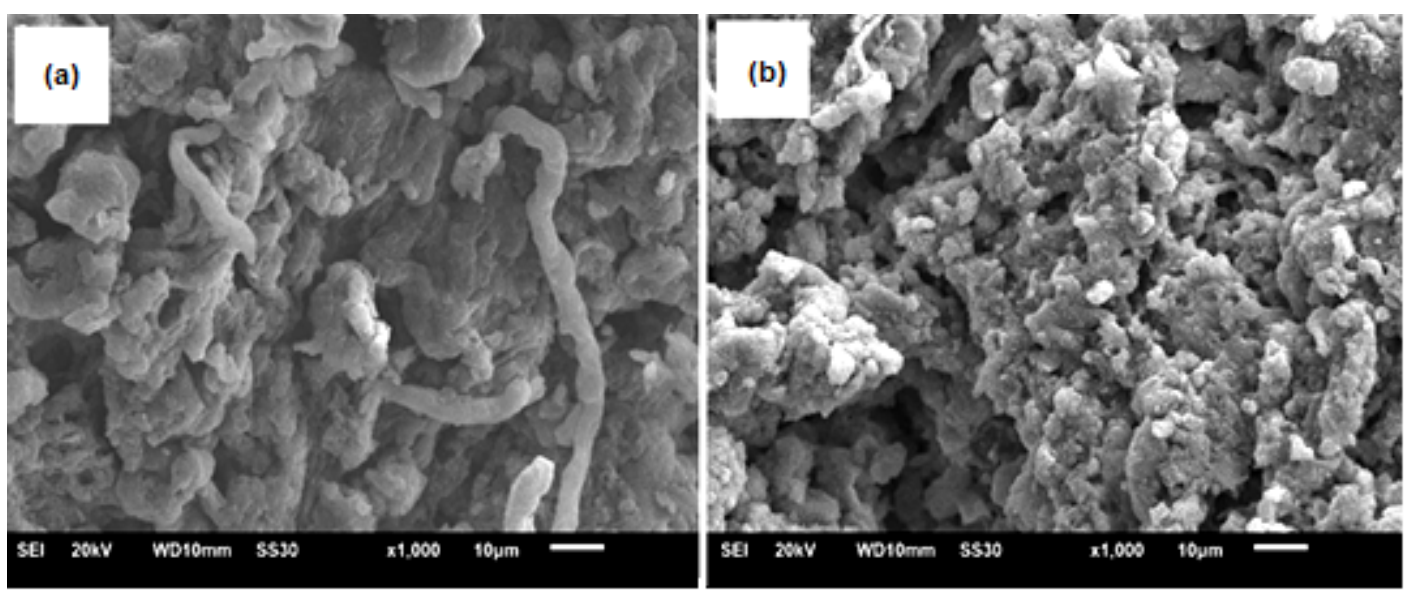

Fig 4. SEM micrograph; (a) GEL-A; (b) GEL-B

SEM characterization was used to study the morphological surface of the hydrogels. In Fig. 4, GEL-A displays a heterogeneous structure, while GEL-B has a relatively more uniform surface with the presence of several small pores. Interestingly, the structure of the fibrils can be observed on the surface (Fig. 4(a)). This fibrous structure is possible due to the cellulose chain's selfassociation at low temperature, which becomes more obvious and orderly with the increase of gelation concentration [8]. With the addition of the carboxymethyl group to GEL-B, it was observed that the particle size decreased. Moreover, the number of pores increased, leading to an open and loose structure (Fig. 4(b)). This shows that the electrostatic repulsion caused by the carboxylic anions $\left(-\mathrm{COO}^{-}\right)$character had enlarged the space in the hydrogel network. Therefore, the swelling ratio increased because water molecules can easily diffuse in hydrogel material [27].

The differences in chemical structure between cellulose and hydrogels were characterized by FTIR, and the results are shown in Fig. 5. For the isolated cellulose spectrum (Fig. 5(a)), several typical absorption peaks can be seen, including the stretching of the $-\mathrm{OH}$ group at wave number $3447 \mathrm{~cm}^{-1}$ [28-29], the $-\mathrm{CH}$ group at wave number $2897 \mathrm{~cm}^{-1}$, the $\mathrm{C}-\mathrm{C}$ group at wave number $1643-1425 \mathrm{~cm}^{-1}$, reinforced by the stretching vibrations of the $\mathrm{C}-\mathrm{O}$ group at wave number $1273-1063 \mathrm{~cm}^{-1}$ [28], and the 1,4- $\beta$ glycosidic bonds at wave number $895 \mathrm{~cm}^{-1}$ [30]. In the GEL-A spectrum (Fig. 5(b)), the broad absorption peak at wave number $3451 \mathrm{~cm}^{-1}$ is the stretching of the $-\mathrm{OH}$ group on the polymer backbone. The stretching of the aliphatic - $\mathrm{CH}$ group is shown at wave number $2922 \mathrm{~cm}^{-1}$ and the absorption peak shows the glycosidic bond (C-O-C) at $898 \mathrm{~cm}^{-1}$. Meanwhile, in the GEL-B spectrum (Fig. 5(c)), changes in absorption bands and conical peaks for the $-\mathrm{OH}$ group at wave number $3439 \mathrm{~cm}^{-1}$ have been observed. On the other hand, the aliphatic $-\mathrm{CH}$ absorption band increases to $3173 \mathrm{~cm}^{-1}$, and also the C-O-C group shifts to $866 \mathrm{~cm}^{-1}$ with a sharper peak [11]. Compared to GEL-A, the absorption band observed at wave number 1603 and $1460 \mathrm{~cm}^{-1}$ can be associated with asymmetric stretching of the carboxylic anion $\left(-\mathrm{COO}^{-}\right)$and buckling $-\mathrm{OH}$ in the carboxylic spectrum $[8,31]$. The $\mathrm{C}-\mathrm{O}$ group appears at wave numbers $1139 \mathrm{~cm}^{-1}$ and $1059 \mathrm{~cm}^{-1}$. The results showed that there is a carboxyl group in GEL-B [32].

In Fig. 5(d) and Fig. 5(e), the FTIR spectrum of hydrogels after being soaked with urea solution is shown. 


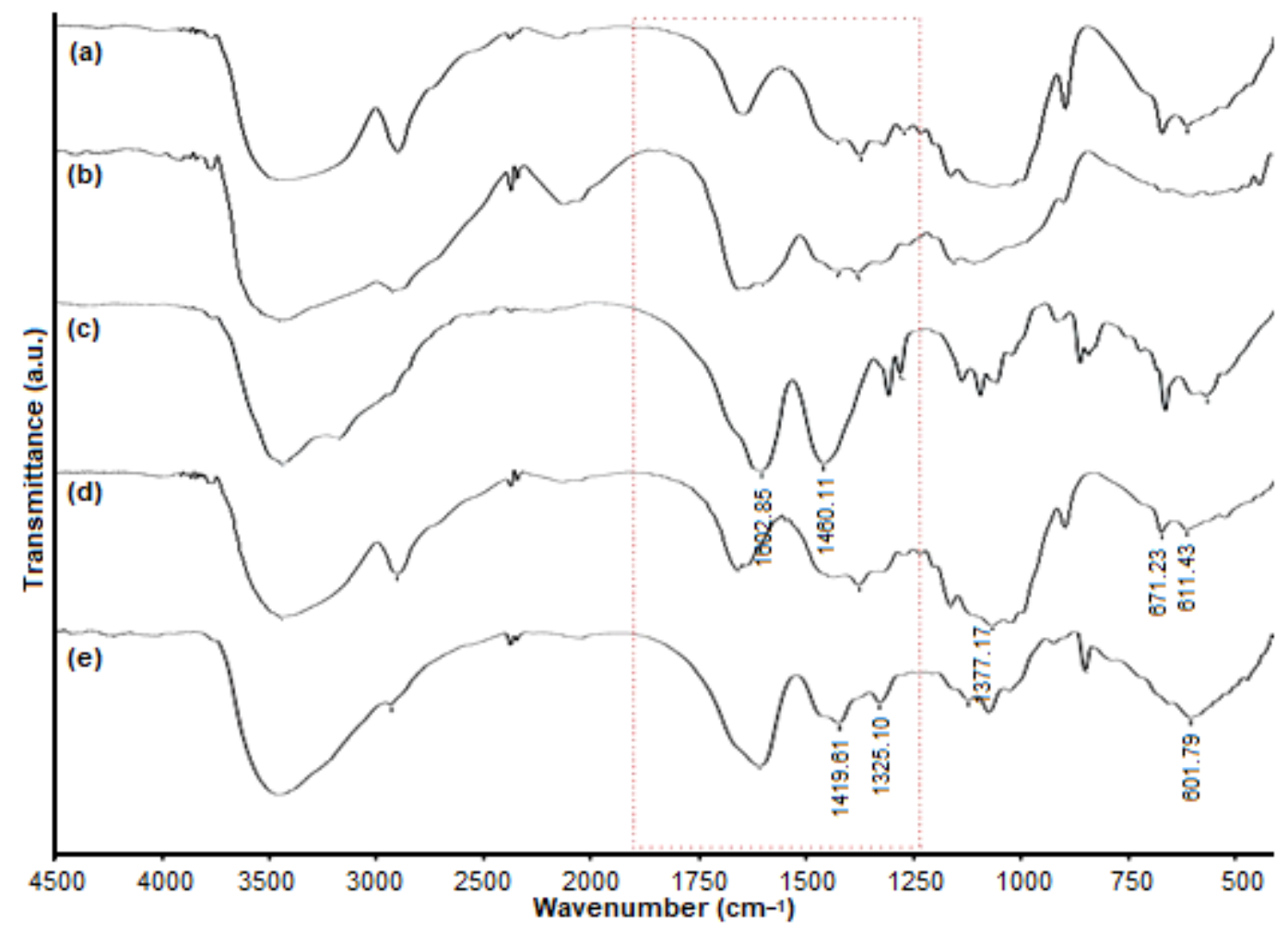

Fig 5. FTIR spectrum; (a) cellulose, (b) GEL-A before immersion, (c) GEL-B before immersion, (d) GEL-A after immersion, (e) GEL-B after immersion

The absorption peaks at wave numbers 3449 and $3445 \mathrm{~cm}^{-1}$ indicate the presence of the $-\mathrm{OH}$ group and the stretching of $\mathrm{C}-\mathrm{H}$ was observed at wave numbers 2899 and $2928 \mathrm{~cm}^{-1}$ [33]. Other peaks observed are absorption bands at wave numbers 1659 and 1603, 1377 and 1325-1419, and areas around $1000-1250 \mathrm{~cm}^{-1}$, indicating the presence of carboxylic anion $\left(-\mathrm{COO}^{-}\right)$and $\mathrm{N}-\mathrm{H}$, as well as $\mathrm{C}-\mathrm{O}$ or $\mathrm{C}-$ $\mathrm{N}[2,31,34]$. Absorption peaks at wave numbers 611-671 and $602 \mathrm{~cm}^{-1}$ are associated with $\mathrm{N}-\mathrm{CO}-\mathrm{N}$ flexural vibrations, showing urea involvement in GEL-A and GEL-B [34].

\section{Urea Released from GEL-A and GEL-B}

The release of urea from the hydrogels is presented in Fig. 6. Due to its high urea solubility in water, it can be assumed that without a carrier matrix, almost 100\% release of urea in water will occur within minutes [25].

In the hydrogels of controlled urea, the maximum release of urea concentration from GEL-A occurred in $90 \mathrm{~min}$ and it was shown by a decrease in urea concentration from $95.26 \mathrm{ppm}$ to $94.46 \mathrm{ppm}$. Thus, the

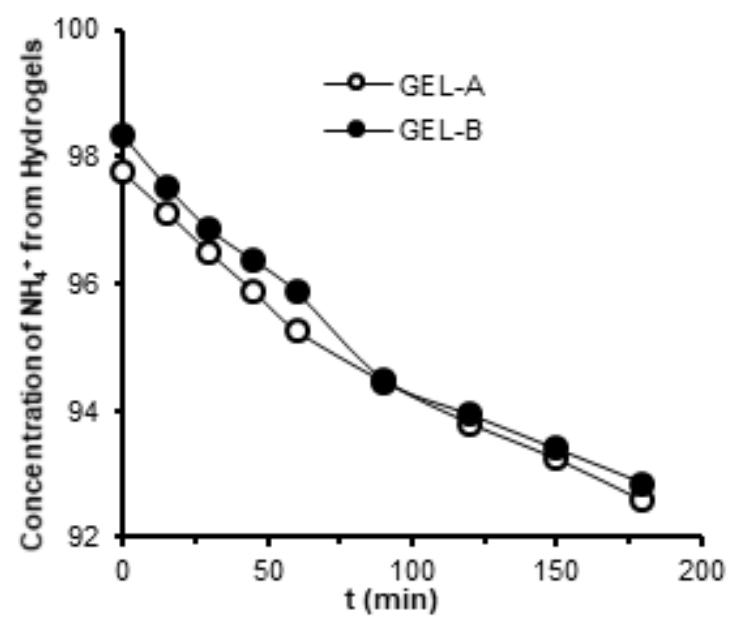

Fig 6. Slow-release of urea from hydrogels

total urea released in the $180 \mathrm{~min}$ period was $5.17 \mathrm{ppm}$ or $5.29 \%$ of the amount of fertilizer absorbed. On the the other hand, in GEL-B, the total urea released was $5.47 \mathrm{ppm}$ or $5.56 \%$. After the water entered the hydrogel layer, the fertilizer in the core was dissolved and then released in water [32]. In short, the hydrogels will gradually swell and act as a physical barrier that inhibits 
the diffusion of nutrients from the polymer tissue, then the fertilizer will gradually dissolve and be released with increasing time through water exchange when the hydrogels are applied to the soil [24]. The mechanism of urea release from the hydrogel matrix is studied using the equation:

$\mathrm{M}_{\mathrm{t}} / \mathrm{M}_{\infty}=\mathrm{Kt}^{\mathrm{n}}$

where $M_{t}$ is the amount of urea released at time $t, M_{\infty}$ is the total amount of urea present in the initial matrix, $\mathrm{M}_{\mathrm{t}} / \mathrm{M}_{\infty}$ is the fraction of urea released at time t. $\mathrm{n}=1$ is a continuous zero-order release, $0.5<\mathrm{n}<1$ is a non-Fickian diffusion release, and $\mathrm{n}<0.5$ is the release dominated by Fickian diffusion. The index $\mathrm{n}$ can be determined by plotting $\log \mathrm{M}_{\mathrm{t}} / \mathrm{M}_{\infty}$ against the $\mathrm{Kt}^{\mathrm{n}} \log$ (Fig. 7 and Fig. 8) and determining the slope of the line obtained:

$\log \left(\mathrm{M}_{\mathrm{t}} / \mathrm{M}_{\infty}\right)=\mathrm{n} \log (\mathrm{t})+\log (\mathrm{K})$

Based on the above equation, the obtained $n$ values of GEL-A ( $n=-0.0195)$ and GEL-B ( $n=-0.0207)$ showed the release of Fickian diffusion $(n<0.5)$. The recommended release mechanism to release the urea from the hydrogels is in a "partition" manner, where the solute moves through the interface and the area of the bound to the gel with polymer matrix [35].

The influence of $\mathrm{pH}$ on the release of urea from the hydrogel material is shown in Fig. 9. The release by GEL-B was faster than GEL-A. If the cation concentration increases, there is an increase in osmotic pressure in the gel system which eventually causes shrinkage within [26]. This is explained by the protonation of $-\mathrm{COO}^{-}$to

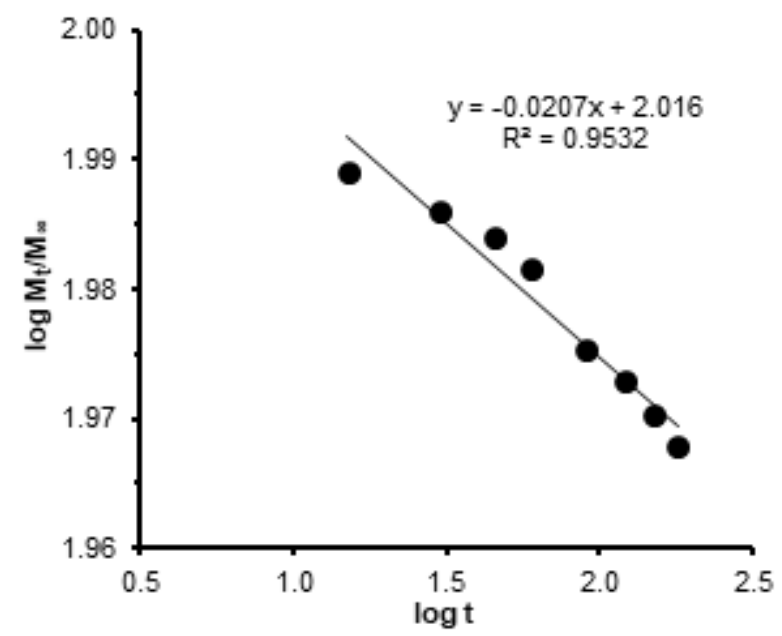

Fig 8. Index $n$ of GEL-B
$-\mathrm{COOH}$ and the formation of hydrogen bonds between $-\mathrm{COOH}$ at acidic $\mathrm{pH}$, which restrains the electrostatic repulsion of anions, increases the cross-linking of tissues, and consequently decreases water absorption [24]. However, in a certain $\mathrm{pH}$ range close to neutrality (pH 6-8), most of the base groups and acid groups are non-ionizing, so the $\mathrm{H}$-bond between amine acid and carboxylic acid or carbox-amide group can produce a kind of cross-linking followed by a decreased swelling. With a further increase in $\mathrm{pH}$, there is an electrostatic repulsion force between the $-\mathrm{COO}^{-}$group and ionization of the carboxylic acid group. As a result, there is an expansion of the polymeric tissue which causes an increase in water absorption and swelling, subsequently, the release of urea increases and reaches a maximum at $\mathrm{pH} 9$ [36]. The presence of additional ions can obviously

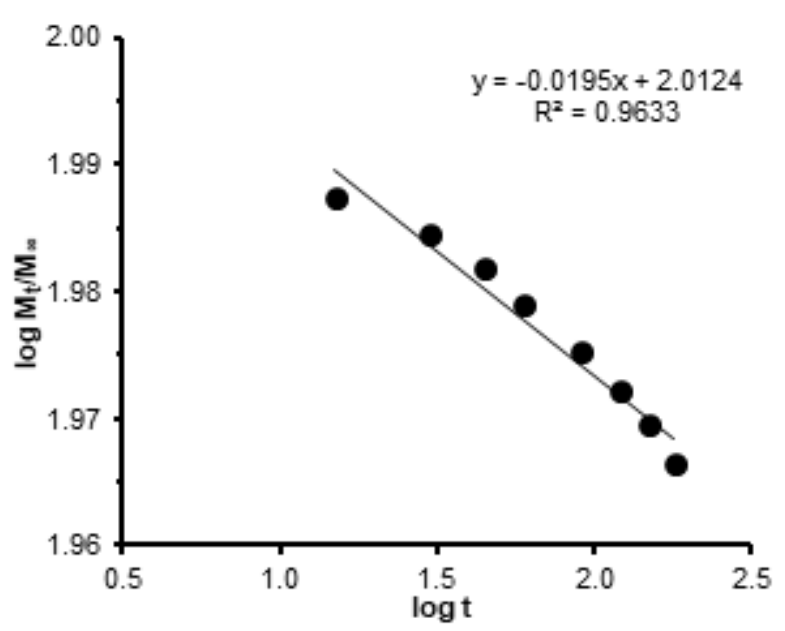

Fig 7. Index $n$ of GEL-A

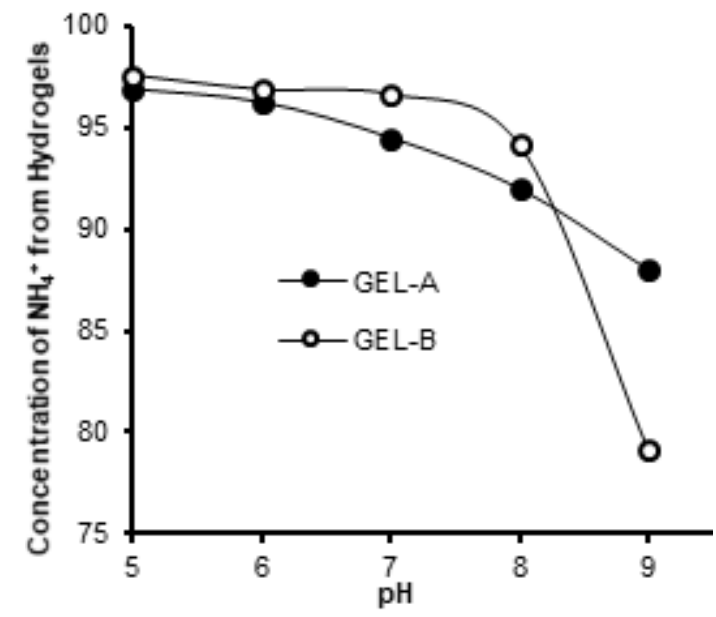

Fig 9. Effect of $\mathrm{pH}$ on urea release from hydrogels 


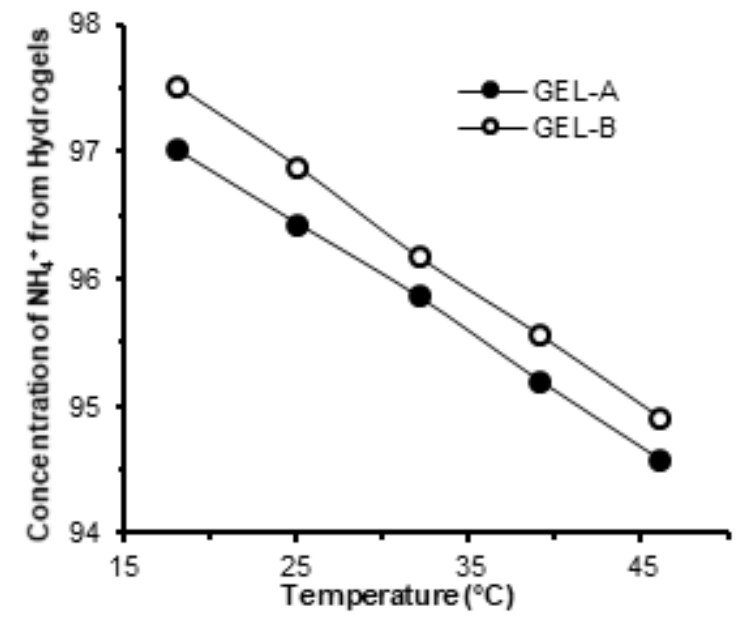

Fig 10. Effect of temperature on urea release from hydrogels

cause a slower rate of swelling and lower swelling capacity. Existing cations can produce greater fertilizer diffusion. Ions derived from the addition of a buffer solution can also play a role in increasing the concentration of urea in the release media. This means that the cations in water can accelerate the release of fertilizers by competing for adsorption sites, competitive complexing, etc. [37].

Slow-release fertilizer or controlled-release fertilizer can release nutrients due to two factors: humidity and temperature. Generally, the higher the temperature and the more available water vapors are, the faster the release of urea is [38]. This statement is in accordance with the graph in Fig. 10 which shows that as the temperature increases, the release of urea takes place quickly. Thus, the amount of urea in GEL-A has decreased from an initial concentration of 97.75 to $94.59 \mathrm{ppm}$. Whereas in GEL-B, the amount of urea released decreased from the initial concentration of 98.33 to $94.52 \mathrm{ppm}$. In the hydrophilic region, water molecules are connected by side chains through hydrogen bonds and work cooperatively to form a stable hydration shell around the hydrophobic groups. All of these interactions cause good solubility at room temperature. When the temperature rises, this system needs more energy to destroy this interaction and free trapped water molecules [39]. Lee and Yuan [40] also explained that the hydrophilic group in the polymer structure will form intermolecular hydrogen bonds between molecules with the surrounding water at low temperatures. Therefore, water that penetrates into the gel is bound to a low temperature. The water molecule will gain enthalpy during the rise in temperature, and the hydrophilic groups in the gel will be converted into intramolecular hydrogen bonds under this condition. At the same time, hydrophobic strength will increase. These two results make the water molecules in the gel change from a bonded state to a free state and detached from the gel tissue with the release of urea. The level of immersion of the hydrogels that are sensitive to temperature also depends on the degree of water distribution. Faster response rate can be achieved if the water trapped in the hydrogels can quickly spread [36].

\section{- CONCLUSION}

Superabsorbent hydrogels have been successfully synthesized and have shown their performance as the release material of controlled-release urea fertilizer. The formed GEL-A was better than GEL-B because the combination of urea and hydrogels produced a stable release of urea with a relatively lower amount of urea released (5.29\%). Hydrogel application requires $\mathrm{pH}$ control.

\section{- REFERENCES}

[1] Trenkel, M.E., 2010, Slow and Controlled Release and Stabilized Fertilizers: An Option for Enhancing Nutrient Use Efficiency in Agriculture, $2^{\text {nd }}$ Ed., International Fertilizer Industry Association (IFA), Paris, France.

[2] Liu, M., Liang, R., Zhan, F., Liu, Z., and Niu, A., 2007, Preparation of superabsorbent slow release nitrogen fertilizer by inverse suspension polymerization, Polym. Int., 56 (6), 729-737.

[3] Talaat, H.A., Sorour, M.H., Aboulnour, A.G., Shaalan, H.F., Ahmed, E.M., Awad, A.M., and Ahmed, M.A., 2008, Development of a multicomponent fertilizing hydrogel with relevant techno-economic indicators, Am. Eurasian J. Agric. Environ. Sci., 3 (5), 764-770.

[4] Puoci, F., Iemma, F., Spizzirri, U.G., Cirillo, G., Curcio, M., and Picci, N., 2008, Polymer in agriculture: A review, Am. J. Agric. Biol. Sci., 3 (1), 299-314. 
[5] Azeem, B., KuShaari, K., Man, Z.B., Basit, A., and Thanh, T.H., 2014, Review on materials and methods to produce controlled release coated urea fertilizer, $J$. Controlled Release, 181, 11-21.

[6] Zohuriaan-Mehr, M.J., and Kabiri, K., 2008, Superabsorbent polymer materials: A review, Iran. Polym. J., 17 (6), 451-477.

[7] Kabir, S.M.F., Sikdar, P.P., Haque, B., Bhuiyan, M.A.R., Ali, A., and Islam, M.N., 2018, Cellulosebased hydrogels materials: Chemistry, properties, and their prospective applications, Prog. Biomater., 7 (3), 153-174.

[8] Chang, C., Duan, B., Cai, J., and Zhang, L., 2010, Superabsorbent hydrogels based on cellulose for smart swelling and controllable delivery, Eur. Polym. J., 46 (1), 92-100.

[9] Ibrahim, S.M., El Salmawi, K.M., and Zahran, A.H., 2007, Synthesis of crosslinked superabsorbent carboxymethyl cellulose/acrylamide hydrogels through electron-beam irradiation, J. Appl. Polym. Sci., 104 (3), 2003-2008.

[10] Murthy, P.S.K., Mohan, Y.M., Varaprasad, K., Sreedhar, B., and Raju, K.M., 2008, First successful design of semi-IPN hydrogels-silver nanocomposites: A facile approach for antibacterial application, $J$. Colloid Interface Sci., 318 (2), 217-224.

[11] Muharam, S., Yuningsih, L.M., and Sumitra, M.R., 2017, Characterization of superabsorbent hydrogels based on epichlorohydrin crosslink and carboxymethyl functionalization of cassava starch, AIP Conf. Proc., 1862, 030083.

[12] Yusnaidar, Wirjosentono, B., Thamrin, and Eddiyanto, 2017, Synthesized superabsorbent based on cellulose from rice straw for controlled-release of urea, Orient. J. Chem., 33 (4), 1905-1913.

[13] National Standardization Agency of Indonesia, 1991, SNI 06-2479-1991, Metode pengujian kadar amonium dalam air dengan alat spektrofotometer secara nessler, National Standardization Agency of Indonesia, Jakarta, Indonesia.

[14] Effendi, F., Elvia, R., and Amir, H., 2018, Preparasi dan karakterisasi mikrokristalin selulosa (MCC) berbahan baku tandan kosong kelapa sawit (TKKS), Alotrop, 2 (1), 52-57.

[15] Johar, N., Ahmad, I., and Dufresne, A., 2012, Extraction, preparation and characterization of cellulose fibres and nanocrystal from rice husk, Ind. Crops Prod., 37 (1), 93-99.

[16] Zulharmitta, Viora, L., and Rivai, H., 2011, Pembuatan mikrokristalin selulosa dari batang rumput gajah (Pennisetum purpureum Schumach), Jurnal Farmasi Higea, 3 (2), 102-111.

[17] Kabiri, K., and Zohuriaan-Mehr, M.J., 2004, Porous superabsorbent hydrogels composites: Synthesis, morphology and swelling rate, Macromol. Mater. Eng., 289 (7), 653-661.

[18] Cai, J., and Zhang, L., 2006, Unique gelation behavior of cellulose in $\mathrm{NaOH} / \mathrm{urea}$ aqueous solution, Biomacromolecules, 7 (1), 183-189.

[19] Ciolacu, D.E., and Suflet, D.M., 2018, "Cellulosebased hydrogels for medical/pharmaceutical applications" in Biomass as Renewable Raw Material to Obtain Bioproduct of High-Tech Value, Eds. Popa, V., and Volf, I., Elsevier, Romania, 401439.

[20] Udoetok, I.A., Dimmick, R.M., Wilson, L.D., and Headley, J.V., 2016, Adsorption properties of crosslinked cellulose-epichlorohydrin polymers in aqueous solution, Carbohydr. Polym., 136, 329-340.

[21] Sangseethong, K., Ketsilp, S., and Sriroth, K., 2005, The role of reaction parameters on the preparation and properties of carboxymethyl cassava starch, Starch/Stärke, 57 (2), 84-93.

[22] Toğrul, H., and Arslan, N., 2003, Production of carboxymethyl cellulose from sugar beet pulp cellulose and rheological behaviour of carboxymethyl cellulose, Carbohydr. Polym., 54 (1), 73-82.

[23] Adeyanju, O., Olademehin, O.P., Hussaini, Y., Nwanta, U.C., Adejoh, A.I., and Plavec, J., 2016, Synthesis, and characterization of carboxymethyl Plectranthus esculentus starch. A potential disintegrant, J. Pharm. Appl. Chem., 2 (3), 189-195.

[24] Wen, P., Han, Y., Wu, Z., He, Y., Ye, B.C., and Wang, J., 2017, Rapid synthesis of a corncob-based 
semi-interpenetrating polymer network slow-release nitrogen fertilizer by microwave irradiation to control water and nutrient losses, Arabian J. Chem., 10 (7), 922-934.

[25] Mohammadi-Khoo, S., Moghadam, P.N., Fareghi, A.R., and Movagharnezhad, N., 2016, Synthesis of a cellulose-based hydrogels network: Characterization and study of urea fertilizer slow release, J. Appl. Polym. Sci., 133 (5), 42935.

[26] Shah, R., Saha, N., and Saha, P., 2015, Influence of temperature, $\mathrm{pH}$ and simulated biological solutions on swelling and structural properties of biomineralized $\left(\mathrm{CaCO}_{3}\right)$ PVP-CMC hydrogels, Prog. Biomater., 4, 123-136.

[27] Chang, C., Zhang, L., Zhou, J., Zhang, L., and Kennedy, J.F., 2010, Structure and properties of hydrogels prepared from cellulose in $\mathrm{NaOH} /$ urea aqueous solutions, Carbohydr. Polym., 82 (1), 122-127.

[28] Mohadi, R., Saputra, A., Hidayati, N., and Lesbani, A., 2014, Studi interaksi ion logam $\mathrm{Mn}^{2+}$ dengan selulosa dari serbuk kayu, Jurnal Kimia, 8 (1), 1-8.

[29] Hutomo, G.S., Marseno, D.W., Anggrahini, S., and Supriyanto, 2012, Ekstraksi selulosa dari pod husk kakao menggunakan sodium hidroksida, Agritech, 32 (3), 223-229.

[30] Viera, R.G.P., Filho, G.R., de Assunção, R.M.N., Meireles, C.S., Vieira, J.G., and de Oliveira, G.S., 2007, Synthesis and characterization of methylcellulose from sugar cane bagasse cellulose, Carbohydr. Polym., 67 (2), 182-189.

[31] Silverstein, R.M., Webster, F.X., and Kiemle, D.J., 2005, Spectrometric Identification of Organic Compounds, $7^{\text {th }}$ Ed., John Wiley \& Sons, Hoboken, New Jersey, USA.

[32] Wang, J., Liu, S., Qin, Y., Chen, X., Xing, R., Yu, H., Li, K., and Li, P., 2017, Preparation and characterization of controlled-release fertilizers coated with marine polysaccharides derivates, Chin. J. Oceanol. Limnol., 35 (5), 1086-1093.
[33] Ni, B., Liu, M., and Lü, S., 2009, Multifunctional slow-release urea fertilizer from ethylcellulose and superabsorbent coated formulations, Chem. Eng. J., 155 (3), 892-898.

[34] Wen, P., Wu, Z., He, Y., Han, Y., and Tong, Y., 2016, Characterization of $\mathrm{p}(\mathrm{AA}-\mathrm{co}-\mathrm{AM}) / \mathrm{bent} / \mathrm{urea}$ and its swelling and slow release behavior in a simulative soil environment, J. Appl. Polym. Sci., 133 (12), 43082.

[35] Lynch, I., and Dawson, K.A., 2004, Release of model compounds from "plum-pudding"-type gels composed of microgel particles randomly dispersed in a gel matrix, J. Phys. Chem. B, 108 (30), 1089310898.

[36] Zhao, Y., Su, H., Fang, L., and Tan, T., 2005, Superabsorbent hydrogels from poly(aspartic acid) with salt-, temperature- and $\mathrm{pH}$ - responsiveness properties, Polymer, 46 (14), 5368-5376.

[37] Li, X., Li, Q., Xu, X., Su, Y., Yue, Q., and Gao, B., 2015, Characterization, swelling and slow-release properties of e new controlled release fertilizer based on wheat straw cellulose hydrogels, J. Taiwan Inst. Chem. Eng., 60, 564-572.

[38] Rose, R., 2002, Slow release fertilizers 101, Dumroese, R.K., Riley, L.E., and Landis, T.D., Technical coordinators, National Proceedings: Forest and Conservation Nursery Associations-1999, 2000, and 2001, Proceedings RMRS-P-24, Ogden, UT., USDA Forest Service, Rocky Mountain Research Station, 304-308.

[39] Zhang, X., and Zhuo, R., 2000, Synthesis of temperature-sensitive poly( $N$-isopropylacrylamide) hydrogels with the improved surface property, $J$. Colloid Interface Sci., 223 (2), 311-313.

[40] Lee, W.F., and Yuan, W.Y., 2000, Thermoreversible hydrogels $\mathrm{X}$ : synthesis and swelling behavior of the ( $N$-isopropylacrylamide-co-sodium 2-acrylamido2-methylpropyl sulfonate) copolymeric hydrogels, J. Appl. Polym. Sci., 77 (8), 1760-1768. 